\title{
Methanococcus infernus sp. nov., a novel hyperthermophilic lithotrophic methanogen isolated from a deep-sea hydrothermal vent
}

\author{
C. Jeanthon, ${ }^{1}$ S. L'Haridon, ${ }^{1}$ A. L. Reysenbach, ${ }^{2}$ Marc Vernet, ${ }^{1}$ \\ P. Messner, ${ }^{3}$ U. B. Sleytr ${ }^{3}$ and D. Prieur ${ }^{1,4}$
}

\author{
Author for correspondence: C. Jeanthon. Tel: +3329 8292 309. Fax: + 33298292324 . \\ e-mail: jeanthon@sb-roscoff.fr
}

\footnotetext{
Station Biologique, UPR9042, Centre National de la Recherche

Scientifique and Université Pierre et Marie Curie, Place Georges-Teissier, 29680 Roscoff, France

2 Department of Biochemistry and Microbiology, Cook College, Rutgers University, New Brunswick, NJ 08903, USA

3 Zentrum für Ultrastrukturforschung und Ludwig BoltzmannInstitut für Molekulare Nanotechnologie, Universităt für Bodenkultur, 1180 Wien, Austria

4 Université de Bretagne Occidentale, UFR des Sciences et Techniques, 6 avenue Victor Le Gorgeu, 29285 Brest cedex, France
}

\begin{abstract}
An autotrophic, extremely thermophilic methanogen (ME') was isolated from a deep-sea hydrothermal chimney sample collected on the Mid-Atlantic Ridge at a depth of $3000 \mathrm{~m}$. The heavily flagellated cells are motile and coccoid shaped. The new strain grows between 55 and $91{ }^{\circ} \mathrm{C}$, with an optimum growth temperature at $85^{\circ} \mathrm{C}$. The optimum pH for growth is 6.5 , and the optimum sea salt concentration for growth is around $25 \mathrm{~g} \mathrm{I}^{-1}$. The organism uses $\mathrm{H}_{2}$ and $\mathrm{CO}_{2}$ as the only substrate for growth and methane production. Tungsten, selenium and yeast extract stimulate growth significantly. In the presence of $\mathrm{CO}_{2}$ and $\mathrm{H}_{2}$, the organism reduces elemental sulphur to hydrogen sulphide. The $\mathrm{G}+\mathrm{C}$ content of the genomic DNA is $33 \mathrm{~mol} \%$. As determined by 165 gene sequence analysis, this organism is closely related to Methanococcus jannaschii strain JAL-1'. However, no significant homology was observed between them with DNA-DNA hybridization. It is proposed that this organism should be placed in a new species, Methanococcus infernus. The type strain is ME $^{\top}$ (=DSM 11812').
\end{abstract}

Keywords: deep-sea hydrothermal vents, thermophiles, Archaea, Methanococcus, Methanococcus infernus

\section{INTRODUCTION}

Marine hyperthermophilic methanogens that have been isolated from shallow water systems and deep-sea hydrothermal vents (Stetter, 1996a) belong to the genera Methanococcus and Methanopyrus. Methanococcus thermolithotrophicus strain $\mathrm{SN}-\mathrm{I}^{\mathrm{T}}$ isolated from coastal geothermally heated sediments close to Naples (Italy), was the first extremely thermophilic methanogen to be described (Huber et al., 1982). A selenium-independent hyperthermophilic methanogen, Methanococcus igneus strain $\mathrm{Kol} 5^{\mathrm{T}}$, was isolated from a shallow submarine hydrothermal vent (Kolbeinsey ridge, Iceland) (Burggraf et al., 1990). Methanopyrus kandleri, which represents one of the most extreme members of hyperthermophiles known so far, was isolated from the same shallow marine

The GenBank/EMBL/DDBJ accession number for the 165 rRNA sequence of $M^{\top}$ is AF025822. system (Kurr et al., 1991). This organism also thrives in hydrothermally heated deep-sea sediments in the Guaymas Basin (Kurr et al., 1991; C. Jeanthon, unpublished results). Futhermore, Methanococcus jannaschii strain $\mathrm{JAL}-1^{\mathrm{T}}$ and closely related isolates have been isolated exclusively from the Guaymas Basin (Jones et al., 1983, 1989; Zhao et al., 1988). In this paper we described the isolation and the characteristics of a novel extremely thermophilic Methanococcus isolated from a deep-sea hydrothermal vent chimney collected at $14^{\circ} 45^{\prime} \mathrm{N}$ on the Mid-Atlantic Ridge.

\section{METHODS}

Reference strains. $M$. jannaschii strain JAL- ${ }^{\mathrm{T}}$ (DSM 2661 ${ }^{\mathrm{T}}$ ), $M$. igneus strain $\mathrm{Kol} 5^{\mathrm{T}}\left(\mathrm{DSM} 5666^{\mathrm{T}}\right)$ and $M$. thermolithotrophicus strain SN-1 ${ }^{\mathrm{T}}$ (DSM 2095 ${ }^{\mathrm{T}}$ ) were obtained from the DSMZ-Deutsche Sammlung von Mikroorganismen und Zellkulturen (Braunschweig, Germany).

Collection of chimney samples. During the Microsmoke cruise (November and December 1995), a chimney was 
collected from the Logatchev hydrothermal field $\left(14^{\circ} 45^{\prime} \mathrm{N}\right.$, $44^{\circ} 59^{\prime} \mathrm{W}$ ) on the Mid-Atlantic Ridge at a depth of $3000 \mathrm{~m}$ (Krasnov et al., 1995). The chimney was collected by the port manipulator of the manned submersible Nautile and stored in an insulated basket during retrieval to the surface. On board, subsampling across the sulphide structure was conducted as aseptically as possible. Chimney subsamples were transferred in $50 \mathrm{ml}$ glass vials and immersed with a sterile solution of $3 \%(\mathrm{w} / \mathrm{v})$ sea salts (Sigma). The vials were closed tightly with butyl rubber stoppers (Bellco), pressurized with $\mathrm{N}_{2}(100 \mathrm{kPa})$, reduced with sodium sulphide if required, and stored at $4{ }^{\circ} \mathrm{C}$ until processed further.

Enrichment cultures and purification. Enrichments were performed anaerobically in 50 or $100 \mathrm{ml}$ vials containing 10 or $20 \mathrm{ml}$ medium, respectively, according to Miller \& Wolin (1974). The enrichment medium consisted of $\left(1^{-1}\right.$ distilled water): $30 \mathrm{~g}$ sea salts, $1 \mathrm{~g} \mathrm{NH}_{4} \mathrm{Cl}, 0.35 \mathrm{~g} \mathrm{KH}_{2} \mathrm{PO}_{4}, 3.46 \mathrm{~g}$ PIPES, $1 \mathrm{~g} \mathrm{NaHCO}_{3}, 2 \mathrm{~g}$ Difco yeast extract, $2 \mathrm{~g}$ Difco peptone, $1 \mathrm{~g}$ sodium acetate, $0.5 \mathrm{~g}$ cysteine. $\mathrm{HCl}, 1 \mathrm{ml}$ trace element mixture (Widdel \& Bak, 1992), $50 \mathrm{mg}$ selenate, $30 \mathrm{mg}$ tungstate, $1 \mathrm{ml}$ vitamin mixture (Widdel \& Bak, 1992), $1 \mathrm{ml}$ thiamin solution (Widdel \& Bak, 1992), $0.05 \mathrm{mg}$ vitamin $\mathrm{B}_{12}, 1 \mathrm{ml}$ growth-stimulating factors (Pfennig et al., 1981 ) and $1 \mathrm{mg}$ resazurin. The $\mathrm{pH}$ was adjusted to 6.5 using $\mathrm{HCl} 1 \mathrm{M}$ before autoclaving and the medium was reduced by adding appropriate amounts of sodium sulphide $\left(\mathrm{Na}_{2} \mathrm{~S} .9 \mathrm{H}_{2} \mathrm{O}\right) . \mathrm{H}_{2} / \mathrm{CO}_{2}[80: 20 ; 200 \mathrm{kPa}$ (above atmospheric pressure)] was used as the gas phase. Unless indicated otherwise, cultures were incubated at $80^{\circ} \mathrm{C}$ and the $\mathrm{pH}$ of the medium was readjusted after $1 \mathrm{~h}$ incubation. Positive enrichments were subcultured into the same medium without yeast extract, peptone and acetate (minimum medium, MM). Single colonies were obtained and purified by streaking onto MM that was reduced with a titanium(III) citrate solution (Zehnder \& Wuhrman, 1976) and solidified with $0.7 \%(\mathrm{w} / \mathrm{v})$ Phytagel (a gellan gum from Sigma). Plates were incubated in anaerobic jars at $75^{\circ} \mathrm{C}$ for $3 \mathrm{~d}$ under a $\mathrm{H}_{2} / \mathrm{CO}_{2}$ atmosphere $(80: 20 ; 300 \mathrm{kPa})$. Stock cultures of the isolate $\mathrm{ME}$ were stored in culture medium at $4{ }^{\circ} \mathrm{C}$. For long term storage, pure cultures were stored at $-80^{\circ} \mathrm{C}$ in the same medium containing $20 \%$ (w/v) glycerol.

Determination of growth. Growth was determined by measuring changes in turbidity at $600 \mathrm{~nm}$ with a Spectronic 20D spectrophotometer (Bioblock). Direct cell counts were determined using cells stained with acridine orange and counted by epifluorescence microscopy using an ocular grid (Hobbie et al., 1977). All growth experiments were performed in duplicate.

Determination of growth parameters. The influence of the $\mathrm{pH}$ on growth was determined in the $\mathrm{MM}$ with various buffers at a concentration of $10 \mathrm{mM}$; acetate/acetic acid buffer from $\mathrm{pH} 4$ to 5, MES at $\mathrm{pH} 5.5$ and 6.0, PIPES buffer at $\mathrm{pH} 6.5$ and $7 \cdot 0$, HEPES buffer at $\mathrm{pH} 7.5$, Tris at $\mathrm{pH} 8$ and 8.5 . The $\mathrm{pH}$ of the medium was adjusted after one hour of incubation at the optimal temperature of growth. To determine the salt requirement, $\mathrm{MM}$ was prepared with different dilutions of sea salts. The effects of $\mathrm{pH}$ and salinity were determined at the optimal temperature for growth.

Determination of growth requirements. To investigate the ability to use substrates other than $\mathrm{H}_{2}$, acetate $\left(2 \mathrm{~g} \mathrm{l}^{-1}\right)$, formate $\left(5 \mathrm{~g} \mathrm{l}^{-1}\right)$, methanol $(0.5 \% ; \mathrm{v} / \mathrm{v})$, monomethylamine $\left(2 \mathrm{gl}^{-1}\right)$, and yeast extract $\left(2 \mathrm{~g}^{-1}\right)$ were added individually to the $\mathrm{MM}$ and with a $\mathrm{N}_{2} / \mathrm{CO}_{2}$ gas phase $(80: 20 ; 200 \mathrm{kPa})$. The same compounds added individually in the MM without bicarbonate at the same concentrations were tested as possible carbon sources by using $\mathrm{H}_{2}(100 \% ; 200 \mathrm{kPa})$ as the gas phase. Selected nitrogenous compounds were tested for suitability as nitrogen sources, using ammonium-free mineral medium (Widdel \& Bak, 1992). Nitrogenous compounds were added at $10 \mathrm{mM}$ final concentrations. Electron acceptors were tested in the same medium without $\mathrm{Na}_{2} \mathrm{SO}_{4}$. To determine their potential stimulatory effects on the growth yield, the vitamin mixture, trace element solution, yeast extract, tungstate, and selenate were tested individually in the basal medium that consisted of $\left(1^{-1}\right.$ distilled water $)$ : 30 g sea salts, $1 \mathrm{~g} \mathrm{NH}_{4} \mathrm{Cl}, 0.35 \mathrm{~g} \mathrm{KH}_{2} \mathrm{PO}_{4}, 3.46 \mathrm{~g}$ PIPES, $1 \mathrm{~g}$ $\mathrm{NaHCO}_{3}, 0.5 \mathrm{~g}$ cysteine. $\mathrm{HCl}$, and $1 \mathrm{mg}$ resazurin. The $\mathrm{pH}$ was adjusted as before and $\mathrm{H}_{2} / \mathrm{CO}_{2}(80: 20 ; 200 \mathrm{kPa})$ was used as the gas phase.

Antibiotic susceptibility. Sensitivity of strain $\mathrm{ME}^{\mathrm{T}}$ to chloramphenicol $\left(75 \mu \mathrm{g} \mathrm{ml}^{-1}\right)$, penicillin $\mathrm{G}\left(200 \mu \mathrm{g} \mathrm{ml}^{-1}\right)$, streptomycin $\left(200 \mu \mathrm{g} \mathrm{ml}^{-1}\right)$, kanamycin $\left(200 \mu \mathrm{g} \mathrm{ml}^{-1}\right)$, ampicillin $\left(200 \mu \mathrm{g} \mathrm{ml}^{-1}\right)$ and rifampicin $\left(50 \mu \mathrm{g} \mathrm{m}^{-1}\right)$ (all from Sigma) was tested at $80^{\circ} \mathrm{C}$. Simultaneous experiments were performed with the thermophilic methanogens $M$. jannaschii strain $\mathrm{JAL}-1^{\mathrm{T}}$ and $M$. igneus strain $\mathrm{Kol} 5^{\mathrm{T}}$ at $80^{\circ} \mathrm{C}$ and $M$. thermolithotrophicus strain $\mathrm{SN}-1^{\mathrm{T}}$ at $65^{\circ} \mathrm{C}$.

Microscopy. An Olympus BH-2 microscope equipped with an Olympus OM-2 camera was used routinely to observe and count the cells. For negative staining, $20 \mu \mathrm{l}$ bacterial suspension fixed with $2 \%(\mathrm{w} / \mathrm{v})$ glutaraldehyde was dropped on Formvar/carbon-coated grids (400 mesh) and stained with $4 \%(\mathrm{w} / \mathrm{v})$ uranyl acetate. Preparations of cells for freeze-fracturing and ultrathin sectioning was performed as described previously (Sleytr et al., 1988). Electron micrographs were taken on a model CM100 electron microscope (Philips) with an acceleration voltage of $80 \mathrm{kV}$.

$\mathrm{H}_{2} \mathrm{~S}$ production. $\mathrm{H}_{2} \mathrm{~S}$ production was evaluated by adding $500 \mu \mathrm{l}$ of a solution of $\mathrm{CuSO}_{4}(5 \mathrm{mM})$ and $\mathrm{HCl}(50 \mathrm{mM})$ to $250 \mu \mathrm{l}$ of a culture grown at $85^{\circ} \mathrm{C}$. The dark brown precipitate demonstrating its presence was compared to that of the uninoculated medium incubated in the same conditions.

Methane determination. Methane was measured with a Girdel model 3000 gas chromatograph equipped with a thermal conductivity detector. Samples $(0.5 \mathrm{ml})$ were injected onto a Poropak Q (80-100 mesh) column and eluted with helium at a flow rate of $12 \mathrm{ml} \mathrm{min}^{-1}$. Temperatures were as follows: injector, ambient temperature; column, $60^{\circ} \mathrm{C}$; detector, $150^{\circ} \mathrm{C}$. These conditions allowed us to follow methane production and hydrogen consumption simultaneously.

Isolation of DNA. Genomic DNA of strain $\mathrm{ME}^{\mathrm{T}}$ was isolated by using the procedure described by Charbonnier \& Forterre (1994). The DNA was purified on a caesium chloride gradient (Sambrook et al., 1989) and purity was checked spectrophotometrically.

DNA base composition. The $\mathrm{G}+\mathrm{C}$ content of the DNA was determined from the melting point according to Marmur \& Doty (1962) using DNA (Sigma) from Escherichia coli (57 $\mathrm{mol} \% \mathrm{G}+\mathrm{C})$, Clostridium perfringens $(26.5 \mathrm{~mol} \% \mathrm{G}+\mathrm{C})$ and Micrococcus luteus $(77 \mathrm{~mol} \% \mathrm{G}+\mathrm{C})$ as standards.

Small-subunit rDNA sequencing after PCR amplification. The 16S rDNA (16S rDNA) was amplified by PCR as described previously (Reysenbach et al., 1992). The double-stranded PCR products were sequenced with an ABI 373 automated sequencer. The $16 \mathrm{~S}$ rDNA sequences were aligned manually with a representative set of $16 \mathrm{~S}$ rRNA sequences obtained from the Ribosomal Database Project (Maidak et al., 1996) 
or from recent GenBank releases. The GenBank accession numbers for the 16S rRNA sequences reported in this paper are as follows: Methanococcus jannaschii JAL-1 ${ }^{\mathrm{T}}$, M59126; Methanococcus thermolithotrophicus SN-1 ${ }^{\mathrm{T}}$, M59128; Methanococcus igneus Kol 5 ${ }^{\mathrm{T}}$, M59125; Methanococcus voltae PS ${ }^{\mathrm{T}}$, M59290; and 'Methanococcus aeolicus' A, U39016. The secondary structure was used as a guide to ensure that only homologous regions were compared. A total of 1429 nucleotides were sequenced, and 1377 were used in the phylogenetic analysis. The absence of chimeric molecules was ensured by using the secondary sequence and computer analyses. The phylogenetic trees were constructed either with evolutionary distance matrices, using the program of De Soete (1983), or by maximum-likelihood analysis, using the program fastDNAml (Olsen et al., 1994). Bootstrap values were obtained for maximum-likelihood analysis by using 100 replicate trees and random addition of sequence.

DNA homology. Genetic relatedness was investigated by slot-blot DNA-DNA hybridization by using a randomprime labelling and signal amplification system (Amersham Life Sciences) following the procedure described by Kristjánsson et al. (1994). Increasing amounts of target DNA (50-200 ng) denatured in $0.4 \mathrm{M} \mathrm{NaOH}$ were slotted onto a nylon hybridization membrane (Bio-Rad) and probed with $200 \mathrm{ng}$ labelled tracer DNA. For each duplicate of DNA-DNA association (15 h in buffer $4 \times$ SSC with formamide, $0.5 \%$ blocking agent, $5 \%$ dextran sulphate, $100 \mu \mathrm{g}$ denatured sheared salmon sperm DNA ml ${ }^{-1}$ ), the temperature of hybridization chosen was in the optimal range in the hybridization buffer (Johnson, 1984; Ivanova et al., 1988). Final high-stringency washes and signal amplification were performed according to the manufacturer's instructions. Hybridization signals were detected with a Storm fluorescent scanner (Molecular Dynamics) and analysed by using the IMAGE-QUANT program. Signal (maximum peak area) produced by self-hybridization of the probe with homologous target DNA was set as $100 \%$.

\section{RESULTS}

\section{Enrichment and isolation}

To obtain methanogenic thermophiles, $10 \mathrm{ml}$ enrichment medium was inoculated with approximately $1 \mathrm{ml}$ chimney suspensions. The enrichments were incubated at $80^{\circ} \mathrm{C}$ in $50 \mathrm{ml}$ vials with $\mathrm{H}_{2} / \mathrm{CO}_{2}$ as the gas phase $(80: 20 ; 200 \mathrm{kPa})$ without shaking. Within $2-3 \mathrm{~d}$, turbidity caused by cell growth was observed. This growth consisted of motile and non-motile coccoid cells that fluoresced intense green at $420 \mathrm{~nm}$. All positive enrichment cultures could be successfully transferred into MM. To obtain pure cultures, subcultures were streaked onto solidified medium and incubated in an anaerobic jar with the same gas phase at $75^{\circ} \mathrm{C}$. On solid medium, pale yellow round colonies ( $1 \mathrm{~mm}$ in diameter) were visible after incubation for up to $3 \mathrm{~d}$. One colony was randomly picked and was designated as isolate ME.

\section{Morphology}

Cells of strain $\mathrm{ME}^{\mathrm{T}}$ were irregular cocci, about $1-3 \mu \mathrm{m}$ in diameter (Fig. 1a). Ultrathin sections of whole cells of strain $\mathrm{ME}^{\mathrm{T}}$ possessed the typical archaeal cell
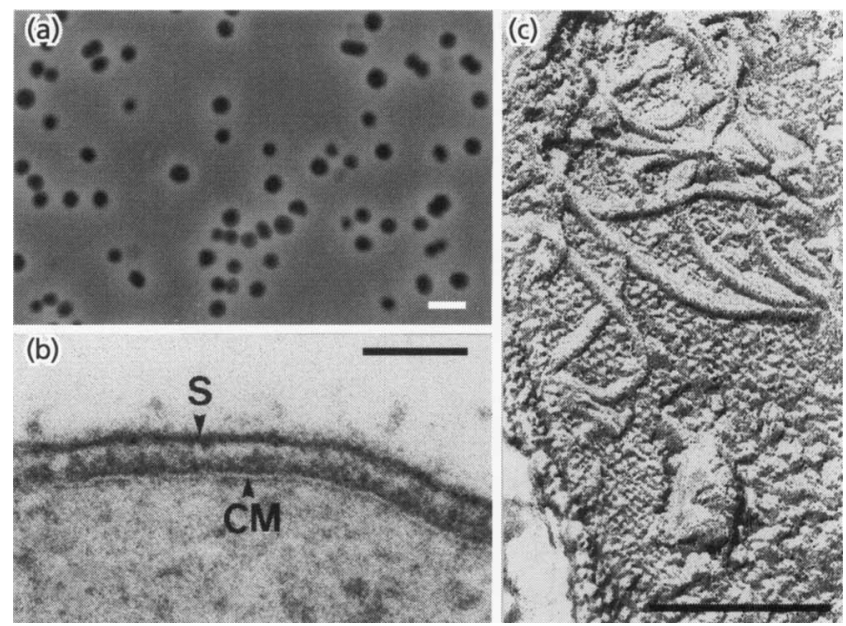

(b)

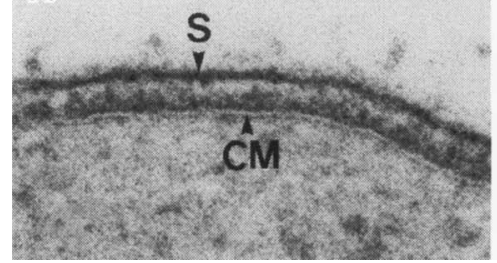

Fig. 1. Phase-contrast micrograph of strain $\mathrm{ME}^{\top}(\mathrm{bar}, 5 \mu \mathrm{m})(\mathrm{a})$ and electron micrographs of strain $\operatorname{ME}^{\top}(b, c)$. Ultrathin sections (b) of whole cells showed the typical archaeal cell envelope profile (bar, $100 \mathrm{~nm}$ ). Freeze-etched and shadowed preparations (c) showed the flagella and the S-layer (bar, $100 \mathrm{~nm}$ ). S, S-layer; CM, cytoplasmic membrane.

envelope profile consisting of the cytoplasmic membrane and a single surface layer (S-layer) (Fig. 1b). They occurred singly or in pairs (Fig. 1a) and exhibited tumbling motility by means of at least three tufts of flagella, each containing a high number of flagella (Fig. 1c). Since the strain was heavily flagellated, parts of flagella were observed even on thin sections. The hexagonal S-layer lattice of strain $\mathrm{ME}^{\mathrm{T}}$ with centre-tocentre spacings of approximately $12.2 \mathrm{~nm}$ was clearly visible (Fig. 1c).

\section{Determination of growth parameters}

Strain $\mathrm{ME}^{\mathrm{T}}$ grew between 55 and $91{ }^{\circ} \mathrm{C}$ with optimum growth around $85^{\circ} \mathrm{C}$, while no growth was detected at 50 and $93{ }^{\circ} \mathrm{C}$ (Fig. 2a). Growth was observed between pH 5.25 and 7.0 , with optimum growth around $\mathrm{pH} 6.5$ (data not shown). Growth could be observed in sea salts concentrations ranging from $12 \cdot 5$ to $50 \mathrm{~g} \mathrm{l}^{-1}$ (Fig. $2 \mathrm{~b}$ ), with an optimum of approximately $25 \mathrm{~g} \mathrm{l}^{-1}$. No growth was observed at 6.25 and $56.25 \mathrm{~g} \mathrm{l}^{-1}$. Under optimal growth conditions (temperature, $\mathrm{pH}$ and $\mathrm{NaCl}$ ), the doubling time of strain $\mathrm{ME}^{\mathrm{T}}$ was approximately $35-40 \mathrm{~min}$.

\section{Determination of growth requirements}

Strain $\mathrm{ME}^{\mathrm{T}}$ is a strictly anaerobic autotrophic organism. Its growth is prevented in the presence of low levels of oxygen and $\mathrm{H}_{2}+\mathrm{CO}_{2}$ serves as the only substrate for growth. Growth was accompanied by exponential methane production which paralleled growth (data not shown). Large amounts of methane (up to $37 \mu \mathrm{mol} \mathrm{ml} l^{-1}$ ) were produced when cells entered the stationary phase. When sulphur was added to the medium in the presence of $\mathrm{CO}_{2}$ and $\mathrm{H}_{2}$, growth 

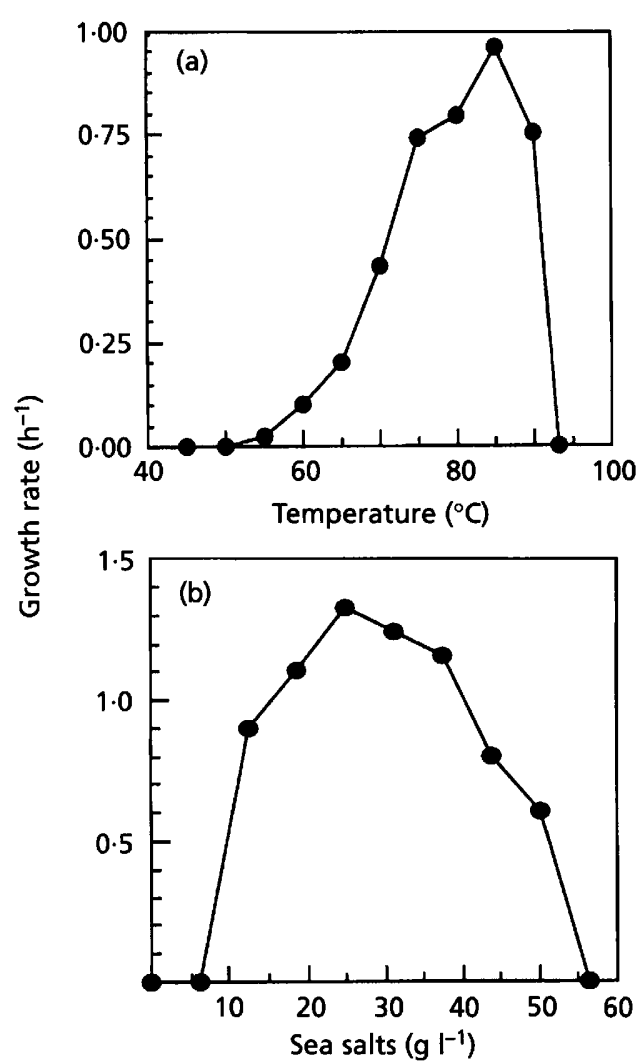

Fig. 2. Growth rates of strain $\mathrm{ME}^{\top}$ as a function of temperature (a) in the presence of sea salts $\left(25 \mathrm{~g} \mathrm{I}^{-1}\right)$ at $\mathrm{pH} 6.5$ and (b) as a function of concentration of sea salts at $85^{\circ} \mathrm{C}$ and at $\mathrm{pH} 6.5$. Growth was followed $\left(A_{600}\right)$ in MM under an atmosphere of $\mathrm{H}_{2} / \mathrm{CO}_{2}(80: 20 ; 200 \mathrm{kPa})$.

occurred and $\mathrm{H}_{2} \mathrm{~S}$ was produced. Nitrate and ammonium were used as nitrogen sources (data not shown). When supplemented individually in the basal medium, the vitamin mixture, tungstate solution, selenate solution and yeast extract stimulated growth whereas trace element solution was found to be slightly inhibitory (data not shown). No growth was observed on acetate, formate, methanol, monomethylamine or yeast extract with a $\mathrm{N}_{2} / \mathrm{CO}_{2}(80: 20 ; 200 \mathrm{kPa})$ or $\mathrm{H}_{2}$ $(100 \% ; 200 \mathrm{kPa})$ headspace. As a control, M. thermolithotrophicus strain $\mathrm{SN}-1^{\mathrm{T}}$ grew on formate at $65^{\circ} \mathrm{C}$ in the presence of $\mathrm{N}_{2} / \mathrm{CO}_{2}$. No dissimilatory reduction of sulphate or thiosulphate was observed.

\section{Sensitivity to antibiotics}

M. jannaschii strain JAL- ${ }^{\mathrm{T}}$, M. igneus strain $\mathrm{Kol} 5^{\mathrm{T}}$, strain $\mathrm{ME}^{\mathrm{T}}$, and $M$. thermolithotrophicus strain $\mathrm{SN}-1^{\text {T }}$ were resistant to ampicillin and kanamycin $(200 \mu \mathrm{g}$ $\left.\mathrm{ml}^{-1}\right)$ and were sensitive to chloramphenicol $(75 \mu \mathrm{g}$ $\mathrm{ml}^{-1}$ ). Among these strains, only $M$. thermolithotrophicus strain $\mathrm{SN}-1^{\mathrm{T}}$ was inhibited by penicillin and streptomycin $\left(200 \mu \mathrm{g} \mathrm{ml}^{-1}\right)$. Finally, M. jannaschii strain $\mathrm{JAL}-1^{\mathrm{T}}$ and strain $\mathrm{ME}^{\mathrm{T}}$ were sensitive to

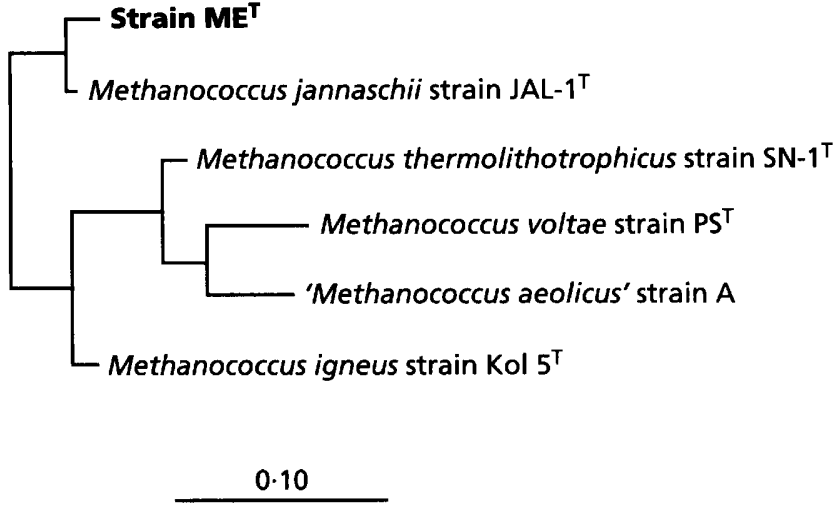

Fig. 3. Phylogenetic relationships of strain $\mathrm{ME}^{\top}$ and other Methanococcales produced by maximum-likelihood analysis. The sequence of the $\mathrm{ME}^{\top}$ small subunit was aligned with other rRNA from the Ribosomal Database Project (17). The scale bar represents the expected number of changes per sequence position.

rifampicin $\left(50 \mu \mathrm{g} \mathrm{ml}^{-1}\right)$ whereas $M$. igneus strain $\mathrm{Kol}$ $5^{\mathrm{T}}$ and $M$. thermolithotrophicus strain $\mathrm{SN}-1^{\mathrm{T}}$ were resistant to this compound.

\section{DNA base composition}

The $\mathrm{G}+\mathrm{C}$ content of the DNA of strain $\mathrm{ME}^{\mathrm{T}}$ determined by the thermal denaturation $\left(T_{\mathrm{m}}\right)$ method was $33 \mathrm{~mol} \%$. As a control, the base composition of Fervidobacterium nodosum was determined to be 35 $\mathrm{mol} \%$ [ $34 \mathrm{~mol} \%$ by the $T_{\mathrm{m}}$ method (Patel et al., 1985) and by direct base analysis reported by (Huber et al., 1990)].

\section{$16 S$ rDNA sequence analysis}

The 16S rDNA sequence analysis placed strain $\mathrm{ME}^{\mathrm{T}}$ as a close relative of $M$. jannaschii strain JAL- ${ }^{\mathrm{T}}$ (Fig. 3 ). Based on their 16S rDNA sequences, a similarity matrix generated using the correction of Jukes \& Cantor (1969) as modified by Olsen et al. (1994) revealed that $\mathrm{ME}^{\mathrm{T}}$ was $96.5 \%$ similar to $M$. jannaschii strain JAL- ${ }^{\mathrm{T}}$. Phylogenetic trees generated using maximum-likelihood analyses and distance matrices were similar. Bootstrap values in both cases place $\mathrm{ME}^{\mathrm{T}}$ unequivocally with $M$. jannaschii strain $\mathrm{JAL}-1^{\mathrm{T}}$ (in $100 \%$ of the samplings of 100 bootstrap resamplings).

\section{DNA-DNA homology}

No significant homology $(<10 \%)$ was obtained between bulk cellular DNA of the isolate $\mathrm{ME}^{\mathrm{T}}$ and $M$. jannaschii strain $\mathrm{JAL}-1^{\mathrm{T}}$.

\section{DISCUSSION}

The novel marine extremely thermophilic strain $\mathrm{ME}^{\mathrm{T}}$ belongs to the archaeal domain on the basis of the cell envelope composition, its resistance to antibiotics, and 
Table 1. Characteristics of Methanococcus species and strain $\mathrm{ME}^{\top}$

\begin{tabular}{|c|c|c|c|c|c|c|c|c|}
\hline \multirow[t]{2}{*}{ Organism } & \multirow[t]{2}{*}{ Motility } & \multicolumn{2}{|c|}{ Temperature $\left({ }^{\circ} \mathrm{C}\right)$} & \multirow[t]{2}{*}{ Substrate } & \multicolumn{3}{|c|}{ Stimulation by: } & \multirow[t]{2}{*}{ Reference } \\
\hline & & Range & Optimum & & Selenium & Tungsten & $\begin{array}{l}\text { Yeast } \\
\text { extract }\end{array}$ & \\
\hline Strain $M E^{T}$ & + & $55-91$ & 85 & $\mathrm{H}_{2}$ & + & + & + & This work \\
\hline M. jannaschii strain JAL-1 ${ }^{\mathrm{T}}$ & + & $50-86^{*}$ & 85 & $\mathrm{H}_{2}^{2}$ & + & $\mathrm{ND}^{\dagger}$ & - & Jones et al. (1983) \\
\hline M. igneus strain Kol $5^{\mathrm{T}}$ & - & $45-91$ & 88 & $\mathrm{H}_{2}$ & - & $\mathrm{ND}$ & + & Burggraf et al. (1990) \\
\hline M. thermolithotrophicus strain $\mathrm{SN}-1^{\mathrm{T}}$ & + & $30-70$ & 65 & $\mathrm{H}_{2}$, formate & ND & - & ND & Huber et al. (1982) \\
\hline
\end{tabular}

ND, Not determined.

* In our laboratory, the maximum growth temperature measured was $91{ }^{\circ} \mathrm{C}$. No growth was obtained at $93^{\circ} \mathrm{C}$.

$\dagger$ In our laboratory, tungstate $\left(30 \mathrm{mg} \mathrm{l}^{-1}\right)$ was found to stimulate growth.

the 16S rDNA sequence (Hilpert et al., 1981; Woese et al., 1990; Sleytr et al., 1996). The morphology, metabolism, $\mathrm{G}+\mathrm{C}$ content and $16 \mathrm{~S}$ rDNA sequence indicate that strain $\mathrm{ME}^{\mathrm{T}}$ belongs to genus Methanococcus.

Strain $\mathrm{ME}^{\mathrm{T}}$ differs from $M$. thermolithotrophicus strain $\mathrm{SN}-1^{\mathrm{T}}$ in its inability to use formate and in its temperature range and optimum for growth (Huber $e t$ al., 1982; Jones et al., 1989). It differs from $M$. igneus strain $\mathrm{Kol} 5^{\mathrm{T}}$ in its temperature range and optimum for growth, its ability to grow in the presence of sulphur, and its positive response to the effect of yeast extract and selenium (Burggraf et al., 1990). The newly described strain $\mathrm{ME}^{\mathrm{T}}$ is most similar to $M$. jannaschii strain JAL- ${ }^{\mathrm{T}}$ with respect to motility, temperature optimum and range for growth (Table 1), and with respect to susceptibility to antibiotics. However, phenotypically, it differs from the type strain JAL- $1^{\text {T }}$ in several aspects. In contrast with strain JAL- ${ }^{\mathrm{T}}$, strain $\mathrm{ME}^{\mathrm{T}}$ did not grow at $50^{\circ} \mathrm{C}$. Moreover, the growth of strain $\mathrm{ME}^{\mathrm{T}}$ in basal medium was enhanced by the presence of yeast extract. This compound has no stimulatory effect on growth of strain JAL- $1^{\mathrm{T}}$ [Jones $e t$ al., 1983; this study (data not shown)].

The results of phylogenetic analyses of 16S rDNA gene sequences indicated that strain $\mathrm{ME}^{\mathrm{T}}$ is related to $M$. jannaschii strain JAL-1 ${ }^{\mathrm{T}}$. The level of $16 \mathrm{~S}$ rDNA sequence similarity between strain $\mathrm{ME}^{\mathrm{T}}$ and this organism $(96.5 \%)$ was less than the limit $(97 \%)$ used to define distinct species at the DNA level without the requirement for DNA-DNA reassociation tests (Stackebrandt \& Goebel, 1994). The low level of genetic relationship between strains $\mathrm{ME}^{\mathrm{T}}$ and JAL-1 ${ }^{\mathrm{T}}$ was confirmed by DNA-DNA hybridization studies, indicating that these organisms cannot be assigned to the same species (Johnson, 1984). From the above results, we concluded that strain $\mathrm{ME}^{\mathrm{T}}$ represents a new Methanococcus species. We propose to name it Methanococcus infernus reflecting its high temperature of growth and the nature of its extreme habitat, the deep-sea hydrothermal vent chimneys.

At the Mid-Atlantic 'Snake Pit' vent, high numbers of cells of Methanopyrus spp. $\left[10^{8}(\mathrm{~g} \text { chimney material })^{-1}\right]$ have been enumerated (Stetter, 1996b). However from an ecological point of view, thermophilic Methanococcus spp. were thought to represent the dominant methanogenic archaea occurring at deep-sea hydrothermal vents (Jones et al., 1989). Our recent survey of thermophilic subpopulations of methanogens at the $23^{\circ} \mathrm{N}$ site on the Mid-Atlantic Ridge seems to confirm this postulate (Harmsen et al., 1997). Futhermore, their widespread occurrence and their diversity in the deep-sea hydrothermal vent sites from Guaymas Basin, East Pacific Rise $\left(13^{\circ} \mathrm{N}\right)$ and Mid-Atlantic Ridge $\left(14.5^{\circ} \mathrm{N}\right.$ and $\left.23^{\circ} \mathrm{N}\right)$ suggests that they may play a significant role in this unique habitat (C. Jeanthon, S. L'Haridon, N. Pradel \& D. Prieur, unpublished results).

\section{Description of Methanococcus infernus sp. nov.}

Methanococcus infernus (in.fer'nus. L. masc. adj. infernus referring to the place of isolation, deep-sea hydrothermal vents).

Cells exhibit a tumbling motility by means of tufts of flagella. They are cocci (diameter, $1-3 \mu \mathrm{m}$ ) and occur singly and in pairs. Pale yellow colonies about $1 \mathrm{~mm}$ in diameter formed on Phytagel plates. Growth occurs between 55 and $91^{\circ} \mathrm{C}$, with an optimum around $85^{\circ} \mathrm{C}$ (doubling time 35-40 min). Growth occurs between pH 5.25 and 7 with an optimum of approximately $\mathrm{pH} 6.5$, and with sea salt concentrations between 12.5 and $56.25 \mathrm{~g} \mathrm{l}^{-1}$ with an optimum of approximately $25 \mathrm{~g} \mathrm{l}^{-1}$. Obligately anaerobic. Chemolithotrophic. Uses $\mathrm{H}_{2}$ and $\mathrm{CO}_{2}$ as energy and carbon sources to produce methane. Growth is stimulated by selenate, tungstate and yeast extract. Sulphur is reduced to hydrogen sulphide in the presence of $\mathrm{CO}_{2}$ and $\mathrm{H}_{2}$. Growth is inhibited by chloramphenicol $\left(75 \mu \mathrm{g} \mathrm{ml}^{-1}\right)$ and rifampicin $\left(50 \mu \mathrm{g} \mathrm{ml}^{-1}\right)$ but not by streptomycin, penicillin $\mathrm{G}$, kanamycin and ampicillin (all at $200 \mu \mathrm{g}$ $\mathrm{ml}^{-1}$ ). DNA base composition of the type strain is 33 $\mathrm{mol} \% \mathrm{G}+\mathrm{C}$ (as determined by the thermal denaturation method). The type strain is Methanococcus infernus $\mathrm{ME}^{\mathrm{T}}$, which was obtained from a deepsea hydrothermal vent chimney at Mid-Atlantic Ridge $\left(14^{\circ} 45^{\prime} \mathrm{N}\right)$. Strain $\mathrm{ME}^{\mathrm{T}}$ has been deposited in the DSMZ-Deutsche Sammlung von Mikroorganismen 
und Zellkulturen under accession number DSM $11812^{\mathrm{T}}$.

\section{ACKNOWLEDGEMENTS}

The excellent technical assistance of Hélène Fouché, Mark Speck, Andrea Scheberl and Monika Miksa is gratefully acknowledged. The Microsmoke cruise was organized by CNRS (D. Prieur, chief scientist) with the N.O. Le Nadir and the D.S. V Nautile operated by IFREMER. We thank the captain and the crew of N.O. Le Nadir and the D.S. V Nautile pilots for skillfull operations and support crew. This work performed at Roscoff was supported by CNRS, GDR 1006 CNRS/IFREMER, CPER 94-95 (Contrat de Plan Etat-Région), Fonds Structurel Européen (FEDER 5b) and MASTIII programmes. Grants from Austrian Science Foundation, project S7201-MOB (to P.M.), and the Austrian Federal Ministy of Science and Transportation supported the work performed at Vienna.

\section{REFERENCES}

Burggraf, S., Fricke, H., Neuner, A., Kristjansson, J., Rouviere, P., Mandelco, L., Woese, C. R. \& Stetter, K. O. (1990). Methanococcus igneus sp. nov., a novel hyperthermophilic methanogen from a shallow submarine hydrothermal system. Syst Appl Microbiol 13, 33-38.

Charbonnier, F. \& Forterre, P. (1994). Comparison of plasmid DNA topology among mesophilic and thermophilic eubacteria and archaebacteria. J Bacteriol 176, 1251-1259.

De Soete, G. (1983). A least squares algorithm for fitting additive trees to proximity data. Psychometrika 48, 621-626.

Harmsen, H. J. M., Prieur, D. \& Jeanthon, C. (1997). Distribution of microorganisms in deep-sea hydrothermal vent chimneys investigated by whole-cell hybridization and enrichments of thermophilic subpopulations. Appl Environ Microbiol 63, 2876-2883.

Hilpert, R., Winter, J., Hammes, W. \& Kandler, O. (1981). The sensitivity of archaebacteria to antibiotics. Zentbl Bakteriol Hyg I Abt Orig C2, 11-20.

Hobbie, J. E., Daley, R. J. \& Jasper, S. (1977). Use of Nuclepore filters for counting bacteria by fluorescence microscopy. Appl Environ Microbiol 33, 1225-1228.

Huber, H., Thomm, M., König, H., Thies, G. \& Stetter, K. O. (1982). Methanococcus thermolithotrophicus, a novel thermophilic lithotrophic methanogen. Arch Microbiol 132, 47-50.

Huber, R., Woese, C. R., Langworthy, T. A., Kristjansson, J. K. \& Stetter, K. O. (1990). Fervidobacterium islandicum sp. nov., a new extremely thermophilic eubacterium belonging to the 'Thermotogales'. Arch Microbiol 154, 105-111.

Ivanova, T. L., Turova, T. P. \& Antonov, A. S. (1988). DNA-DNA hybridization studies on some purple non sulfur bacteria. Syst Appl Microbiol 10, 259-263.

Johnson, J. L. (1984). DNA reassociation and RNA hybridization of bacterial nucleic acids. In Bergey's Manual of Systematic Bacteriology, vol. 1, pp. 8-11. Edited by N. R. Krieg \& J. G. Baltimore: Williams \& Wilkins.

Jones, W. J., Leigh, J. A., Mayer, F., Woese, C. R. \& Wolfe, R. S. (1983). Methanococcus jannaschii, sp. nov., an extremely thermophilic methanogen from a submarine hydrothermal vent. Arch Microbiol 136, 254-261.

Jones, W. J., Stugard, C. E. \& Jannasch, H. W. (1989). Comparison of thermophilic methanogens from submarine hydrothermal vents. Arch Microbiol 151, 214-318.

Jukes, T. H. \& Cantor, C. R. (1969). Evolution of protein molecules. In Mammalian Protein Metabolism, pp. 21-132. Edited by H. N. Munro. New York: Academic Press.

Krasnov, S. G., Cherkashev, G. A., Stepanova, T. V. \& 10 other authors (1995). Detailed geological studies of hydrothermal fields in the North Atlantic. In Hydrothermal Vents and Processes, pp. 43-64. Edited by L. M. Parson, C. L. Walker \& D. R. Dixon. London: The Geological Society.

Kristjánsson, J. K., Hjörleifsdóttir, S., Marteinsson, V. T. \& Alfredsson, G. A. (1994). Thermus scotoductus, sp. nov., a pigment-producing thermophilic bacterium from hot tap water in Iceland and including Thermus sp. X-1. Syst Appl Microbiol 17, 44-50.

Kurr, M., Huber, R., König, H., Jannasch, H. W., Fricke, H., Trincone, A., Kristjansson, J. K. \& Stetter, K. O. (1991). Methanopyrus kandleri, gen. and sp. nov. represents a novel group of hyperthermophilic methanogens, growing at $110^{\circ} \mathrm{C}$. Arch Microbiol 156, 239-247.

Maidak, B. L., Olsen, G. J., Larsen, N., Overbeek, R., McCaughey, M. J. \& Woese, C. R. (1996). The Ribosomal Database Project. Nucleic Acids Res 24, 82-85.

Marmur, J. \& Doty, D. (1962). Determination of the base composition of deoxyribonucleic acid from its thermal denaturation temperature. $J \mathrm{Mol}$ Biol 5, 109-118.

Miller, T. L. \& Wolin, M. J. (1974). A serum bottle modification of Hungate technique for cultivating obligate anaerobes. Appl Environ Microbiol 27, 985-987.

Olsen, G. J., Matsuda, H., Hagstrom, R. \& Overbeek, R. (1994). fastDNAml: a tool for construction of phylogenetic trees of DNA sequences using maximum likelihood. Comput Appl Biosci 10, 41-48.

Patel, B. K. C., Morgan, H. W. \& Daniel, R. M. (1985). Fervidobacterium nodosum gen. nov. and spec. nov., a new chemoorganotrophic, caldoactive, anaerobic bacterium. Arch Microbiol 141, 63-69.

Pfennig, N., Widdel, F. \& Truper, H. G. (1981). The dissimilatory sulfate-reducing bacteria. In The Prokaryotes, 2 nd edn, pp. 926-940. Edited by M. Starr, H. Stolp, H. G. Trüper, A. Balows \& H. G. Schlegel. New York: Springer.

Reysenbach, A.-L., Giver, L. J., Wickham, G. S. \& Pace, N. R. (1992). Differential amplification of rRNA by polymerase chain reaction. Appl Environ Microbiol 58, 3417-3418.

Sambrook, J., Fritch, E. F. \& Maniatis, T. (1989). Molecular Cloning: a Laboratory Manual, 2nd edn. Cold Spring Harbor, NY: Cold Spring Harbor Laboratory.

Sleytr, U. B., Messner, P. \& Pum, D. (1988). Analysis of crystalline bacterial surface layers by freeze-etching, metal-shadowing, negative staining and ultrathin sectioning. Methods Microbiol 20, 29-60.

Sleytr, U. B., Messner, P., Pum, D. \& Sára, D. (1996). Crystalline Bacterial Cell Surface Proteins. London: Academic Press.

Stackebrandt, E. \& Goebel, B. M. (1994). Taxonomic note: a place for DNA-DNA reassociation and 16S rRNA sequence analysis in the present species definition in bacteriology. Int $J$ Syst Bacteriol 44, 846-849.

Stetter, K. O. (1996a). Hyperthermophilic procaryotes. FEMS Microbiol Rev 18, 149-158.

Stetter, K. O. (1996b). Hyperthermophiles in the history of life. In Evolution of Hydrothermal Ecosystems on Earth (and Mars?), 
pp. 1-18. Edited by G. R. Bock \& J. A. Goode. Chichester: Wiley.

Widdel, F. \& Bak, F. (1992). Gram-negative mesophilic sulfatereducing bacteria. In The Prokaryotes, 2nd edn, pp. 3352-3378. Edited by A. Balows, H. G. Trüper, M. Dworkin, W. Harder \& K. H. Schleifer. New York: Springer.

Woese, C. R., Kandler, O. \& Wheelis, M. L. (1990). Towards a natural system of organisms: proposal for the domains
Archaea, Bacteria, and Eucarya. Proc Natl Acad Sci USA 87, 4576-4579.

Zehnder, A. J. B. \& Wuhrman, K. (1976). Titanium(III) citrate as a non-toxic, oxidation-reduction buffering system for the culture of obligate anaerobes. Science 194, 1165-1166.

Zhao, H., Wood, A. G., Widdel, F. \& Bryant, M. P. (1988). An extremely thermophilic Methanococcus from a deep-sea hydrothermal vent and its plasmid. Arch Microbiol 150, 178-183. 